\title{
Biodegradation and Carbon Flow Based on Kelp (Ecklonia maxima) Debris in a Sandy Beach Microcosm
}

\author{
K. Koop, R. C. Newell*, M. I. Lucas* \\ Zoology Department, University of Cape Town, Rondebosch 7700, South Africa
}

\begin{abstract}
Primary decomposition of intertidally stranded kelp Ecklonia maxima in a mixed substrate microcosm is effected by bacteria rather than by fungi, which are generally reported to be responsible for the initial decomposition phases of debris in other habitats. Initial colonisation by cocci along the junctions of epidermal cell walls leads to lysis and release of cell contents. Lysed cells are then colonised by bacterial rods. High concentrations of leachates, reaching $5640 \mathrm{mg}$ carbon $\mathrm{l}^{-1}$ subsequently appear beneath the decomposing kelp. Over $90 \%$ of the carbon in these leachates is utilised by bacteria during drainage through a strip of sand $1 \mathrm{~m}$ long, $50 \mathrm{~cm}$ wide and $12 \mathrm{~cm}$ deep, although on an open beach other organisms, e. g. nematodes, may be capable of direct absorption of such organic matter. Calculation of carbon flow via grazing invertebrates and through bacteria shows that $23-27 \%$ of the carbon in kelp is converted to bacterial carbon. This relationship occurs despite wide variations in direct consumption by grazers, since much of the consumed material is returned to the microcosm as faeces. Estimates of the bacterial carbon in equilibrium with the kelp cast up on the strandline suggest that $1648 \mathrm{~g}$ of kelp carbon is deposited per metre of strandline each $8 \mathrm{~d}$ and that this is capable of supporting a bacterial production of $444.9 \mathrm{~g}$ carbon $\mathrm{m}^{-1}$ of beach per $8 \mathrm{~d}$ cycle; this accords well with recent observations on the biomass of bacteria in the beach itself. The residual $73-77 \%$ of kelp carbon which is not incorporated into bacteria is mineralised by the sand beach microbes within $8 \mathrm{~d}$. The microbial community thus occupies a central role in the rapid regeneration of inorganic materials necessary to support the characteristically high primary production of the kelp bed.
\end{abstract}

\section{INTRODUCTION}

Recent studies on the kelp beds of the west coast of the Cape Peninsula, South Africa, have shown that the standing stock of the 2 dominant kelp species, Ecklonia maxima Osbeck and Laminaria pallida (Grev.) J. Arg. is approximately $6.6 \mathrm{~kg}$ wet weight $\mathrm{m}^{-2}$, and that this yields an annual frond production of as much as $29.4 \mathrm{~kg} \mathrm{~m}^{-2} \mathrm{y}^{-1}$ (Field et al., 1977; Dieckmann, 1978; Mann et al., 1979; Newell et al., 1980). Most of this material enters the water column as dissolved and particulate components during fragmentation (Hatcher et al., 1977; Johnston et al., 1977; Newell et al., 1980) and is estimated to be capable of supporting a bacterial production as high as $14-18 \mathrm{~g}$ dry weight $\mathrm{m}^{-3} \mathrm{y}^{-1}$ in

\footnotetext{
- Present address: Institute for Marine Environmental Research, Prospect Place, The Hoe, Plymouth PL1 3DH, England
}

the nearshore waters adjacent to kelp beds (Field et al., 1980; Linley and Newell, 1981; Linley et al., 1981; Lucas et al., 1981; Newell and Lucas, 1981; Stuart et al., 1981). A proportion of the kelp, probably amounting to some 10-15\% of the standing stock (Jarman and Carter, 1982) is torn free, especially during the winter gales which occur during July and August, and much of it is deposited on nearby beaches. Kelp on the strandline consists principally of the buoyant Ecklonia maxima, while Laminaria pallida tends to fragment and is distributed more widely over the lower shore.

Estimates by Koop and Field (1980) and N. G. Jarman ' (pers. comm.) suggest that between 1200 and $1800 \times 10^{3} \mathrm{~kg}$ wet weight of Ecklonia maxima (about $5 \%$ of the standing stock in the kelp beds) are cast up annually along a $1 \mathrm{~km}$ strandline from a kelp bed of

- Seaweed Laboratory, Sea Fisheries Institute, Sea Point, South Africa 
700 ha at Kommetjie on the west coast of the Cape Peninsula. Muir (1977), Koop and Field (1980, 1981), Stenton-Dozey and Griffiths (1980) and Griffiths and Stenton-Dozey (1981) have shown that much of the material which remains on the surface may be consumed by the amphipod Talorchestia capensis, the isopod Ligia dilatata and larvae of the kelp fly Fucellia capensis. Little is known, however, of the fate of the material voided as faeces or buried beneath sand, nor of the piles of kelp debris on the lower shore. This material is probably degraded by the microfauna and enters the sand column in dissolved and particulate form.

This paper summarises the results of studies made on the relative rates of utilisation of kelp by the dominant consumers and by microheterotrophic decomposer organisms. The results allow us to make some quantitative estimates of the relative significance of consumer organisms and microheterotrophic pathways in the energetics of the sandy beach community.

\section{MATERIALS AND METHODS}

\section{Study Site}

The study site was located at Kommetjie $\left(34^{\circ} 8^{\prime} \mathrm{S}: 18^{\circ} 18^{\prime} \mathrm{E}\right)$, on the west coast of the Cape Peninsula, South Africa. During March 1980 approximately $26 \mathrm{~kg}$ wet weight of freshly cut Ecklonia maxima were placed at high water spring tide level in a cleft with a flat rock floor which drained into a small depression of approximately $10 \mathrm{l}$ volume (Pool 1). Fluids in this pool were used to assay the chemical composition and microbiology of the initial kelp leachates. Excess fluids from this pool drained through a patch of sand of $1 \mathrm{~m}$ length and $50 \mathrm{~cm}$ width with a depth of approximately $12 \mathrm{~cm}$ on an impervious rock floor. Finally, material from the sand could drain into a larger rock pool of 301 volume (Pool 2). The sand strip allowed us to study the role of the interstitial microfauna in the degradation of dissolved and particulate matter entering the beach from the kelp whilst analyses of organic matter entering the larger Pool 2 represented material returned to the sea following processing activities by the sand beach community.

The contents of the pools were first drained and replaced with clean seawater, then the sand was replaced with material from the adjacent dunes so that the amount of leachates from the kelp and the microbial communities associated with them could be followed quantitatively. Microbial densities, numbers of consumer invertebrates and the chemical composition of the leachates and the kelp itself were measured at daily intervals for $8 \mathrm{~d}$ until Pool 2 was inundated by the next spring high tide. All measurements were corrected for evaporative losses from the pools using evaporation dishes. The top layer of the kelp pile dried out very rapidly, effectively preventing desiccation of the underlying plant matter. At the end of the experimental period all but a thin layer of brittle, dried superficial kelp material had disappeared through a combination of grazing by invertebrates and microbial decomposition.

\section{Invertebrate Consumer Species}

It was recognised that removal of invertebrates from the kelp pile to assess consumer densities would affect the rate of consumption. Densities of invertebrate consumers associated with kelp piles were therefore estimated in a subsequent experiment. Eight mesh bags, each containing $2 \mathrm{~kg}$ of fresh Ecklonia maxima were placed on the study site immediately after the initial $8 \mathrm{~d}$ experiment. One bag was removed each day and the numbers and biomass of the associated invertebrates recorded. Biomass was expressed as dry weight, after oven drying at $60^{\circ} \mathrm{C}$ to constant weight.

\section{Microbial Communities}

Microbial communities associated both with the initial degradation of the freshly cut kelp and with the subsequent utilisation of dissolved and particulate matter in the leachates were assayed quantitatively at daily intervals. To estimate the numbers and biomass of bacteria on the surface of the kelp, discs of $1 \mathrm{~cm}$ diameter were punched in fronds and fixed in $1.5 \%$ glutaraldehyde. These were prepared for scanning electron microscopy by a combination of methods described by Todd and Kerr (1972); Paerl (1975), and Bowden (1977). The discs were desalinated, dehydrated through an ethanol series, then fixed in osmium tetroxide before critical point drying and sputter coating with gold palladium. Samples were then viewed on a Cambridge S180 scanning electron microscope.

The numbers of bacteria an the surface of the fronds were estimated from counts on 20 random fields. The biomass was then calculated from measurements of the cell dimensions and values of the specific gravity of bacterial cells (Luria, 1960) using the following expression (Linley et al., 1981; see also Rodina, 1972):

$$
\text { Wet biomass }=\frac{N \cdot V \cdot S G}{10^{6}}
$$

where $N=$ number of cells $\mathrm{mm}^{-2}\left(\times 10^{6}\right) ; V=$ mean volume of the cells $\left(\mu \mathrm{m}^{3}\right) ; S G=$ specific gravity of the cells. The dry biomass and carbon equivalent of the 
wet biomass was then calculated using the coefficients of 0.2 and 0.1 respectively (Luria, 1960; Troitsky and Sorokin, 1967; Sorokin and Kadota, 1972).

The numbers of bacteria in the water column were estimated by acridine orange direct counts (AODC) following filtration onto $0.2 \mu \mathrm{m}$ Nuclepore polycarbonate filters (Hobbie et al., 1977; Linley et al., 1981). Cell dimensions were estimated from scanning electron micrographs of discs of the filters prepared as described by Linley et al. (1981) and biomass estimated as before. Numbers of bacteria in the sand column were assayed following 3 repeated sonications of the sand with a DAWE Sonicleaner Type 6442A. The detached bacteria were then filtered from the eluted sample. The sum of these 2 values was then used to estimate the numbers of bacteria in the microcosm as a whole.

\section{Biochemical Components}

Organic losses from the kelp were assayed both as carbon and component carbohydrates. Samples were taken daily from the kelp fronds, and known volumes were removed from the leachates in Pool 1, the interstitial water of the sand column, and the final drainage Pool 2. They were then freeze-dried and weighed prior to analysis. Since both the volumes and corresponding dry weights of the samples were known, results from analyses of dried material could subsequently be expressed relative to the volume of original sample.

\section{CHN Analysis}

The total carbon and nitrogen content of 3 subsamples of 100 to $200 \mu \mathrm{g}$ of freeze-dried material from both the kelp debris and the liquid material from Pool 1, the interstitial water, and from Pool 2 was measured by combustion in a Carlo Erba elemental analyser (Model 1106) fitted with an integrator (see also Lucas et al., 1981). The nitrogen and carbon content of 5 blank samples of tin cups alone and of triplicate experimental samples was then calculated from the mean peak areas of at least 10 weighed samples of approximately 1.5 to $2.0 \mathrm{mg}$ cyclohexanone (Carlo Erba) containing $20.14 \% \mathrm{~N}$ and $51.79 \% \mathrm{C}$. Inorganic carbon was measured with a Beckman TOC Analyser (Model 915A). The values were generally low, making up no more than $30 \%$ of the total carbon in the pools during the early phases of the experiment and decreasing to as little as $3 \%$ towards Day 8 . Inorganic carbon values were somewhat higher in the interstitial water, accounting for about $70 \%$ on the first $2 \mathrm{~d}$ but also dropping to insignificant levels ( $0.06 \%$ of total carbon) on Day 8.

\section{Total Carbohydrates Excluding Polyols}

Simple sugars, oligosaccharides, polysaccharides and their derivatives - excluding polyols - were colorimetrically estimated from the phenol-sulphuric acid reaction (Dubois et al., 1956). Total carbohydrates were then expressed in terms of 'glucose equivalents' (Lucas et al., 1981) relative to the colour response of a $D$ glucose calibration curve. It should be noted that different reducing sugars give varying degrees of colour response and that alginates also give a weak colour reaction. The latter will thus make a weak contribution to the 'glucose equivalent' values of the sugars.

\section{Polyols and Monosaccharides}

Polyols and monosaccharides were estimated from freeze-dried samples of kelp fronds, leachates and interstitial water following reflux in $200 \mathrm{ml} 80 \%$ ethanol for 2 to $3 \mathrm{~h}$ (Holligan and Drew, 1971). TMS derivatives of the oven-dried extract which included $1.0 \mathrm{ml}$ of an internal standard of meso-erythritol (1.0 $\mathrm{mg} \mathrm{ml}^{-1}$ ), were then assayed by FID gas-liquid chromatography using a modification of the methods described by Newell et al. (1980). Following derivatisation, the samples were centrifuged and $2.5 \mu \mathrm{l}$ of the solvent were injected into preconditioned $\left(6^{\prime} \times 1 / 4^{\prime \prime} \times\right.$ $2 \mathrm{~mm}$ ) columns containing Chromosorb W.H.P. (Varian) solid support (mesh size 100/120) coated with $2 \%$ SE 52 liquid phase. The sugar peaks were resolved with a Varian Series 2700 gas-liquid chromatograph which was temperature programmed to run isothermally for $4 \mathrm{~min}$ after injection, rising to $250^{\circ} \mathrm{C}$ at $6 \mathrm{C}^{\circ}$ $\min ^{-1}$. After reaching the peak temperature, there were periods of 2 min cooling and 4 min equilibration at $125^{\circ} \mathrm{C}$ before the cycle was started again. The relative retention time of D-mannitol was calculated from its distance $(\mathrm{cm})$ relative to the internal standard of meso-erythritol; the latter being fixed relative to the pyridine signal start. The peak heights of all the sugars were corrected to a mean value for the peak height of the meso-erythritol standard. The concentration of Dmannitol in the samples was then calculated from the peak area (relative retention time $\times$ peak height) against concentrations of D-mannitol standards over the range 0.0625 to $0.7500 \mu \mathrm{g} 2.5^{-1} \mu \mathrm{l}$ injected.

\section{Alginates}

Alginates were determined using the method of Blumenkrantz and Asboe-Hansen (1973). We added $1.2 \mathrm{ml}$ of a $0.0125 \mathrm{M}$ solution of sodium tetraborate in concentrated sulphuric acid to $0.2 \mathrm{ml}$ of sample solu- 
Table 1. Numbers ( $N$ ) and biomass ( $B$, mg dry weight) of consumer invertebrates per $\mathrm{kg}$ original fresh weight of kelp Ecklonia maxima on a mixed substrate strandline

\begin{tabular}{|c|c|c|c|c|c|c|}
\hline \multirow[t]{2}{*}{ Day } & \multicolumn{2}{|c|}{$\begin{array}{c}\text { Talorchestia } \\
\text { capensis }\end{array}$} & \multicolumn{2}{|c|}{$\begin{array}{l}\text { Ligia } \\
\text { dilatata }\end{array}$} & \multicolumn{2}{|c|}{$\begin{array}{l}\text { Fucellia } \\
\text { capensis }\end{array}$} \\
\hline & $N$ & B & $N$ & B & $\mathrm{N}$ & B \\
\hline 0 & 0 & 0.00 & 0 & 0.00 & 0 & 0.00 \\
\hline 1 & 730 & 6789.01 & 3 & 65.34 & 58 & 104.98 \\
\hline 2 & 1825 & 16698.83 & 8 & 131.58 & 89 & 153.97 \\
\hline 3 & 1179 & 11825.49 & 56 & 1051.68 & 97 & 188.18 \\
\hline 4 & 760 & 9196.00 & 32 & 617.60 & 125 & 248.75 \\
\hline 5 & 150 & 2055.03 & 5 & 69.87 & 110 & 234.30 \\
\hline 5 & 89 & 1066.28 & 1 & 19.31 & 113 & 240.69 \\
\hline 7 & 32 & 457.64 & 0 & 0.00 & 98 & 194.04 \\
\hline 8 & 11 & 189.89 & 1 & 21.53 & 101 & 190.89 \\
\hline
\end{tabular}

tion containing an estimated $0.5-20 \mu \mathrm{g}$ alginic acid. The mixture was refrigerated in crushed ice, mixed and then heated in a water bath at $100^{\circ} \mathrm{C}$ for $5 \mathrm{~min}$. After cooling in a water/ice bath, $20 \mu \mathrm{l}$ of a $0.15 \%$ solution of m-hydroxydiphenol in $0.5 \% \mathrm{NaOH}$ was added. The mixture was again shaken and the absorbance measured within $10 \mathrm{~min}$ at $520 \mathrm{~nm}$ in a Bausch and Lomb Spectronic 600E spectrophotometer. Because carbohydrates give a colour reaction with sulphuric acid/tetraborate, blank samples were run without addition of the m-hydroxydiphenol which was replaced by $20 \mu \mathrm{l} 0.5 \% \mathrm{NaOH}$. The absorbance of the blank was substracted from the total absorbance and the concentration of alginate in samples calculated from standard curves constructed from assays of commercial alginic acid.

\section{RESULTS AND DISCUSSION}

\section{Numbers and Biomass of Invertebrate Consumers}

The freshly cut kelp was almost immediately invaded by large numbers of the amphipod Talorchestia capensis, which reached a peak biomass of approximately $16.7 \mathrm{~g}$ dry weight $\mathrm{kg}^{-1}$ original wet weight of kelp on Day 2. At the same time the kelp was colonised by smaller numbers of the isopod Ligia dilatata, which reached a peak biomass of approximately $10.5 \mathrm{~g}$ dry weight $\mathrm{kg}^{-1}$ original wet weight of kelp. Larvae of the kelp fly Fucellia capensis appeared on Day 1. In contrast to the crustaceans, however, their biomass remained almost constant at approximately $230 \mathrm{mg}$ dry weight $\mathrm{kg}^{-1}$ wet weight of kelp during much of the period of decomposition of the kelp.

Results are summarised in Table 1. They generally support those obtained by Griffiths and Stenton-Dozey (1981) for colonisation of kelp debris by Fucellia capensis and Talorchestria capensis on an adjacent open sandy beach. Since the period egg to 1st instar of $F$. capensis is as short as 24 to $32 \mathrm{~h}$ (Stenton-Dozey and Griffiths, 1980) it is evident that kelp-fly eggs are laid almost immediately after kelp is deposited on the strandline.

\section{Microbial Colonisation of Kelp Debris on the Strandline}

In all cases initial colonisation and subsequent development of microbial communities followed a similar pattern. The freshly cut kelp (Day zero) was already sparsely colonised by patches of coccoid bacteria (Fig. 1a) much as has been described for the surface of living kelp and other macrophytes (Sieburth and Thomas, 1973; Laycock, 1974; Cundell et al., 1977; Mazure and Field, 1980; E. A. S. Linley*, pers. comm.). In the first phase of decomposition, which starts after approximately $24 \mathrm{~h}$, distinctive colonisation patterns (Fig. 1 b) are formed, with bacteria aligned along superficial cell borders. This may result either from the migration of bacteria initially present, or from their replacement by others. Subsequently, on Day 3, epidermal lesions develop along the cell boundaries and the contents of the cells swell to form rounded protuberances. The cocci bordering the cells, which are either responsible for, or develop along, the lesion zones can be clearly seen in Fig. 1c.

This phase is followed by shedding of much of the epidermal layer of the kelp, revealing the honeycomblike cells of the underlying parenchymal tissues (Fig. 1d). It is probable that this phase is associated with a major release of dissolved and particulate organic matter from the cell contents, which are known to contain high concentrations of mannitol, laminarin, alginates and other carbohydrates (Jensen and Stein, 1978; Stephen, 1979; Newell et al., 1980). The cell contents and leachates are then colonised by dense communities of rod-like bacteria which often appear to be attached to the kelp surface by fibrils (see also p. 323). Occasional yeasts and fungi also occur (Fig. 1e). A very similar sequential colonisation of kelp exudates by cocci and subsequently by larger rods under culture conditions has been described recently by Linley and Newell, (1981) and Linley et al. (1981).

This sequence of epidermal lysis, followed by bacterial invasion of the cell contents has also been reported in leaves of the mangrove Rhizophora mangle (Cundell et al., 1979), aithough the process of decomposition took nearly 10 times as long as in kelp. HowardWilliams et al. (1978) and Robb et al. (1979) have also found that primary microbial decomposition of the

\footnotetext{
- I.M.E.R., Prospect Place, Plymouth, U.K.
} 

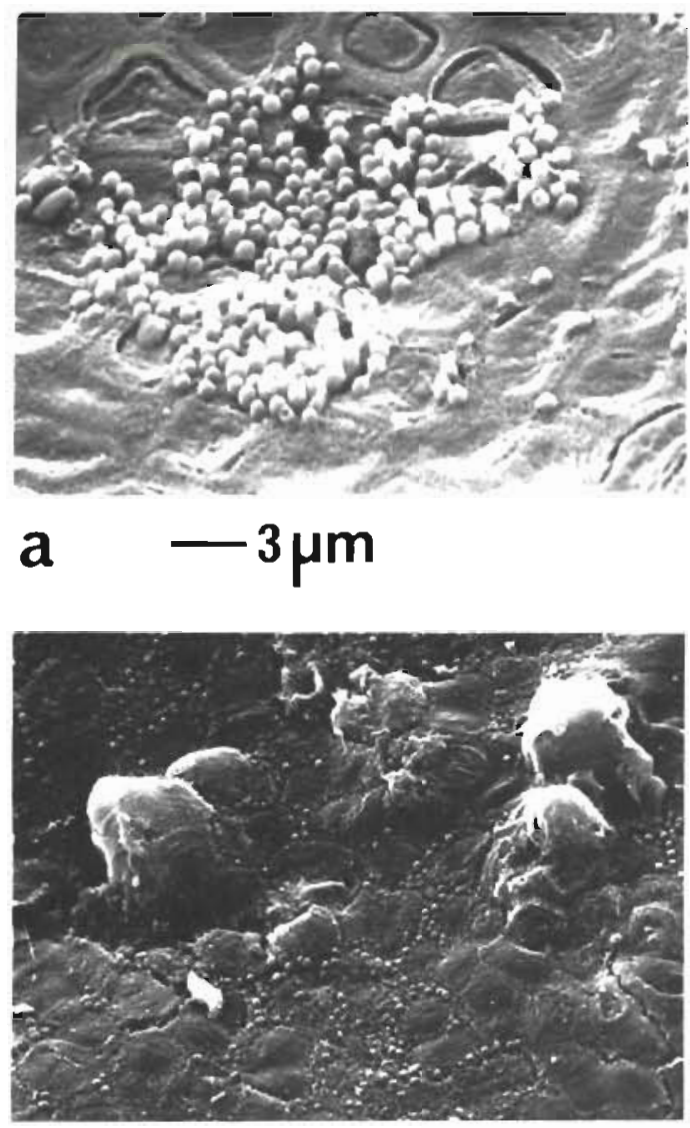

C $10 \mu \mathrm{m}$

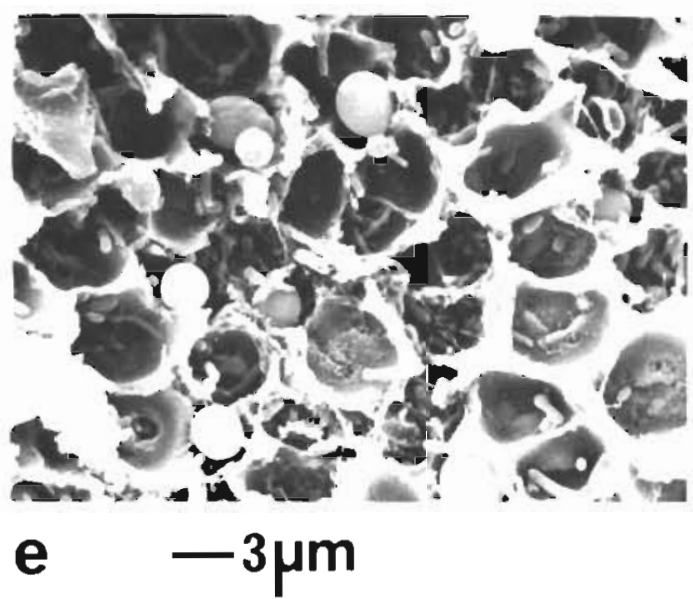

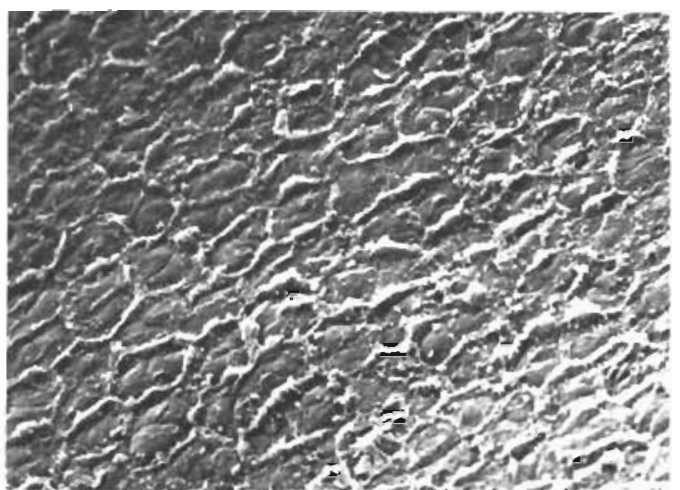

b $-10 \mu \mathrm{m}$
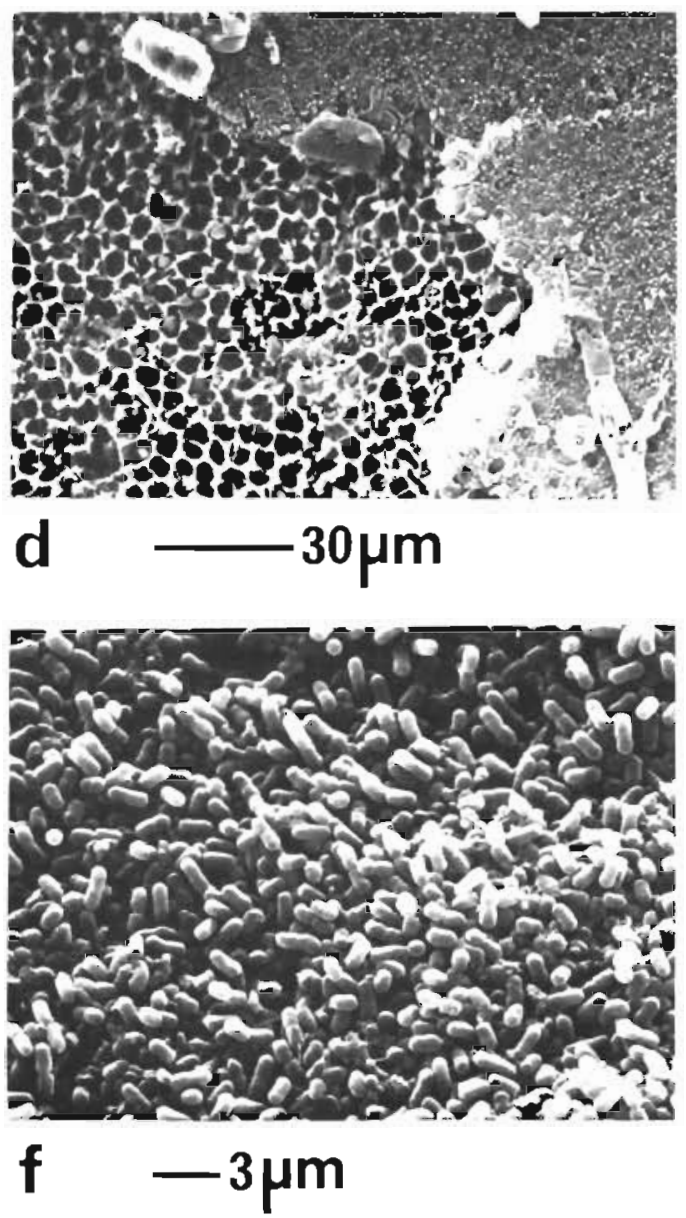

Fig. 1. Selection of stages in the microbial colonisation of Ecklonia maxima debris. (a) Day 0; small bacterial cocci attached to the surface of freshly cut kelp. Fimbriate attachment structures radiate from the point of contact. (b) Day 2: mucilage exudation and bacterial colonisation along cell borders. (c) Day 3: lysis of cell surface. Colonisation of cell borders can be clearly distinguished. (d) Day 6: epidermal lesion leading to exposure of underlying honeycomb-like cells. This phase is associated with major loss of dissolved organic components by leaching. (e) Day 6: colonisation of underlying cells by bacterial rods and some yeasts. (f) Day 8: Inassive population of bacterial rods which dominate the kelp surface during later phases of decomposition 
Table 2. Numbers $\left(\mathrm{N} \mathrm{mm}^{-2}\right)$ and biomass $(\mathrm{B}, \mu \mathrm{g}$ dry weight $\mathrm{mm}^{-2}$ ) of bacteria colonising freshly cut Ecklonia maxima debris on the strandline as a function of time

\begin{tabular}{|cccc|}
\hline Day & $\begin{array}{c}\text { Numbers } \\
\left(.10^{6}\right)\end{array}$ & $\begin{array}{c}\text { Mean vol. } \\
\left(\mu \mathrm{m}^{3}\right)\end{array}$ & Biomass \\
\hline 0 & 0.23 & 0.18 & 9.11 \\
1 & 0.22 & 0.18 & 8.71 \\
2 & 0.43 & 0.21 & 19.87 \\
3 & 0.35 & 0.20 & 15.40 \\
4 & 0.50 & 0.21 & 23.10 \\
5 & 0.60 & 0.21 & 27.72 \\
6 & 0.90 & 0.20 & 39.60 \\
7 & 1.03 & 0.23 & 52.12 \\
8 & 1.24 & 0.41 & 111.85 \\
\hline
\end{tabular}

brackish water sago pond weed Potamogeton pectinatus is associated with bacteria rather than with fungi, which are generally regarded as the initial decomposers of allochthonous material in terrestrial and freshwater habitats (Gessner et al., 1972).

\section{Numbers and Biomass of Bacteria}

Numbers and biomass of bacteria colonising the surface of the kelp debris are shown in Table 2. It should be emphasised that because of the structural complexity of the cell surface following cell lysis from Day 3 onwards, estimates are likely to be minimal. By Day 8 , bacteria became so dense both within the cells and over the whole surface of the debris (Fig. 1f) that accurate counts were not possible. The counts do, however, show a regular increase in bacterial numbers and biomass which reached $112 \mu \mathrm{g}$ dry weight $\mathrm{mm}^{-2} \mathrm{kelp}$ surface by Day 8.

The biomass ( $\mathrm{mg}$ dry weight $1^{-1}$ ) of bacteria colonising the initial leachate in Pool 1, the interstitial water and the sand grains, and the final drainage Pool 2 is

Table 3. Biomass $\left(\mathrm{mg} \mathrm{l}^{-1}\right)$ of bacteria colonising initial leachate from kelp debris (Pool 1), interstitial water and associated sand grains, and final drainage water (Pool 2) as a function of time; ( ) no estimate available

\begin{tabular}{|c|c|c|c|c|c|c|}
\hline \multirow[t]{2}{*}{ Day } & \multirow[t]{2}{*}{ Pool 1} & \multicolumn{3}{|c|}{$\begin{array}{l}\text { Interstitial } \\
\text { community }\end{array}$} & \multirow[t]{2}{*}{ Pool 2} & \multirow[t]{2}{*}{ Tota } \\
\hline & & water & sand & total & & \\
\hline 0 & 0.28 & 0.00 & 0.63 & 0.63 & 0.44 & 1.35 \\
\hline 1 & 5.33 & 0.33 & 5.65 & 5.98 & 1.45 & 12.76 \\
\hline 2 & 18.46 & 0.38 & 4.37 & 4.75 & 2.37 & 25.56 \\
\hline 3 & 23.01 & 1.49 & 3.37 & 4.86 & 3.27 & 31.14 \\
\hline 4 & ( ) & 1.94 & 5.17 & 7.11 & $1)$ & ( ) \\
\hline 5 & 27.30 & 8.91 & 3.77 & 12.68 & 1.76 & 41.74 \\
\hline 6 & 31.85 & 5.98 & 7.75 & 13.73 & 1.42 & 47.00 \\
\hline 7 & 28.60 & 4.57 & 9.19 & 13.76 & 1.84 & 44.20 \\
\hline 8 & 7.25 & 1.60 & 10.61 & 12.21 & 1.63 & 21.09 \\
\hline
\end{tabular}

shown in Table 3. The most obvious feature of the data is that bacterial biomass reached up to $31.85 \mathrm{mg} \mathrm{l}^{-1}$ on Day 6 in the initial leachate, but only $13.76 \mathrm{mg} \mathrm{l}^{-1}$ in the sand community and $3.27 \mathrm{mg} \mathrm{l}^{-1}$ in the lower drainage Pool 2. Clearly, the biomass of bacteria is related to the concentration of organic matter which decreased from the leachate through the sand column and into Pool 2 (see below). After Day 6 the bacterial biomass in the leachate Pool 1 declined, probably reflecting the final phase of release of dissolved organic exudation from the kelp debris. The bacterial biomass in the drainage Pool 2, however, remained at a relatively constant lower value of $1.4-1.8 \mathrm{mg} \mathrm{l}^{-1}$ from Day 5 onwards, suggesting that much of the organic matter from the leachate had been processed in Pool 1 and during its passage through the sand column.

\section{Losses of Organic Components From Kelp Debris}

Removal of Organic Material by Grazing

The amount of kelp debris grazed directly by Talorchestia capensis, Ligia dilatata and Fucellia capensis may be calculated from the biomass (Table 1) and energy budget equations for these organisms (Muir, 1977; Stenton-Dozey and Griffiths, 1980; Koop and Field, 1981). These data are summarised in Table 4

Table 4. Consumption (C), faeces production ( $F$ ) and production (P) and, by difference, respiration (R) in $g$ dry weight of the 3 invertebrate consumer species for the 8-d experiment. $5270 \mathrm{~g}$ dry weight of kelp were originally present. Compiled from the numbers of invertebrates counted in the microcosm, their mean individual weights and the following energy budget equations $(\mathrm{C}=\mathrm{P}+\mathrm{R}+\mathrm{F}+\mathrm{U})$ : Ligia dilatata $\mathrm{C}=$ $0.8 \%+4.2 \%+71.7 \%+()_{i}$ Koop and Field (1981). Talorchestia capensis $\mathrm{C}=2.3 \%+7.4 \%+81.9 \%+5.5 \%$; Muir (1977). Fucellia capensis $\mathrm{C}=17 \%+22 \%+61+()$; Stenton-Dozey and Griffiths (1980). ( ) U not estimated. All data for $\mathrm{C}$ and $\mathrm{W}$ were converted to dry weight from published values

\begin{tabular}{|c|c|c|c|c|}
\hline Species & $\mathrm{C}$ & $F$ & $\mathrm{P}$ & $\mathrm{R}$ \\
\hline Ligia dilatata & 60.71 & 46.72 & 0.49 & 13.50 \\
\hline Talorchestia capensis & 333.85 & 273.42 & 7.65 & 52.78 \\
\hline Fucellia capensis & 73.79 & 45.01 & 12.54 & 16.24 \\
\hline Total & 468.35 & 365.15 & 20.68 & 82.52 \\
\hline$\%$ of kelp in microcosm & 8.89 & 6.93 & 0.39 & 1.57 \\
\hline \multicolumn{5}{|c|}{$\begin{array}{l}\text { Regression equations for consumption vs weight were as } \\
\text { follows: }\end{array}$} \\
\hline \multicolumn{5}{|c|}{ L. dilatata $\quad \begin{aligned} \mathrm{C}=1.15 \quad \mathrm{~W}^{056}(\mathrm{C} & =\mathrm{g} \text { wet wt } 24 \mathrm{~h}^{-1} ; \\
\mathrm{W} & =\mathrm{g} \text { AFDW of individual })\end{aligned}$} \\
\hline T. capensis $\mathrm{C}=0.90 \mathrm{~W}$ & \multicolumn{4}{|c|}{$\begin{aligned} W^{0.23}(\mathrm{C} & =\mathrm{mg} \text { dry } w \mathrm{t} 24 \mathrm{~h}^{-1} \\
\mathrm{~W} & =\mathrm{mg} \text { dry } \mathrm{w} \text { t of individual })\end{aligned}$} \\
\hline F. capensis $\mathrm{C}=0.27 \mathrm{~V}$ & \multicolumn{4}{|c|}{$\mathrm{w}^{0.95}\left(\mathrm{C}=\mathrm{mg}\right.$ dry wt $24 \mathrm{~h}^{-1}$} \\
\hline
\end{tabular}


which shows that the dominant $T$. capensis removes $71 \%$ of the material consumed by grazing organisms. All the grazers are, however, characterised by high consumption rates and low absorption efficiencies, a feature which may result in a high energetic gain in the presence of abundant food resources (Newell, 1980; Newell and Branch, 1980). The table also shows that some $9 \%$ of the kelp was consumed by the grazers in the microcosm and that $7 \%$ was returned as faeces for further decomposition within the system.

These results contrast with those of Griffiths and Stenton-Dozey (1981) who found that $74 \%$ of kelp on the surface of an adjacent open sandy beach was consumed by amphipods and dipteran larvae. It is likely that high consumption rates such as these are characteristic of superficial algal debris which is periodically wetted by the tide or rainfall. Much of the kelp debris is deposited in large piles often covered by sand, making it both anoxic and largely unavailable to surface-dwelling organisms. Under such conditions decomposition rather than consumption by invertebrates is likely to be of importance. Rather variable rates of direct consumption of kelp debris are thus to be anticipated, depending largely on local conditions. In each case, however, the dominant pathway is via the heterotrophic decomposer organisms since up to $80 \%$ of the material consumed by the grazers is returned as faeces and is subsequently decomposed by bacteria (p. 324).

\section{Organic Components of Leachates}

Losses of organic components from the kelp debris by leaching were assessed both in terms of total carbon and nitrogen as well as the principal carbohydrate components mannitol, sugars, laminarins and alginates (Newell et al., 1980).

The carbon values in the leachate Pool 1 , in the interstitial water, and in Pool 2 are shown in Table 5. They represent carbon which had not been mineralised by microheterotrophic organisms. It is evident that very high concentrations (up to $5640 \mathrm{mg} \mathrm{l}^{-1}$ ) occurred in the leachate zone immediately beneath the decomposing kelp debris and that this material was mainly utilised during passage through the $1 \mathrm{~m}$ sand zone. Only some $3-10 \%$ appeared in the final Pool 2 towards the end of the experimental period of $8 \mathrm{~d}$. In addition, ammonia-nitrogen values as high as $69 \mathrm{mg} \mathrm{l}^{-1}$ were recorded in the leachate Pool 1 and these fell during passage through the sand zone to $24.7 \mathrm{mg}$ ammonia- $\mathrm{N}^{-1}$ in drainage Pool 2 .

The high concentrations of dissolved organic carbon which occur beneath the decomposing kelp are in marked contrast to values found in the kelp bed or open oceanic water. R. A. Carter (cited in Newell et al.,
Table 5. Total carbon values ( $\mathrm{mg}^{-1}$ ) in leachates from Ecklonia maxima (Pool 1), in the interstitial water of a $1 \mathrm{~m}$ sand strip and in a subsequent drainage pool (Pool 2). Standard deviations also shown $(n=3)$

\begin{tabular}{|rrrrr|}
\hline Day & \multicolumn{2}{c}{ Pool 1 } & Interstitial & \multicolumn{1}{c|}{ Pool 2 } \\
\hline 0 & $72.54 \pm(1)$ & $160.00 \pm 26.46$ & $96.67 \pm 5.77$ \\
1 & $206.67 \pm$ & 5.77 & $316.67 \pm 25.17$ & $76.67 \pm 5.77$ \\
2 & $633.33 \pm 11.55$ & $266.67 \pm 28.87$ & $76.67 \pm 11.55$ \\
3 & $1250.00 \pm 45.83$ & $240.00 \pm 10.00$ & $136.67 \pm 40.41$ \\
4 & $1536.67 \pm 40.41$ & $243.33 \pm 40.41$ & $113.33 \pm 5.77$ \\
5 & $1906.67 \pm 110.60$ & $303.33 \pm 15.28$ & $103.33 \pm 5.77$ \\
6 & $1286.67 \pm 23.09$ & $170.00 \pm 43.59$ & $103.33 \pm 25.17$ \\
7 & $2656.67 \pm 173.88$ & $166.67 \pm 15.28$ & $126.67 \pm 15.28$ \\
8 & $5640.00 \pm 298.66$ & $126.67 \pm 5.77$ & $190.00 \pm 10.00$ \\
\hline
\end{tabular}

1980) reports a maximal value of $20 \mathrm{mg} \mathrm{l}^{-1}$ in the kelp bed water during periods of strong wave action, when fragmentation of kelp fronds is maximal, falling to less than $5 \mathrm{mg} \mathrm{l}^{-1}$ within $24 \mathrm{~h}$ with the onset of calm weather. Clearly, the bacterial component in the microcosm is capable of rapidly mineralising much of the carbon in the leachates from kelp debris before it is returned by drainage to the sea, and also of utilising some $64 \%$ of the ammonia nitrogen during passage through the sand column.

The concentrations of the principal component carbohydrates in the kelp, in Pool 1, the interstitial water, and in Pool 2 were assayed independently of the carbon. The first and most obvious feature of the results was that D-mannitol, the major primary photosynthate of the kelp which may reach some 5 to $11 \%$ of the dry weight of fronds of Ecklonia maxima depending on season (von Holdt et al., 1955), was very rapidly utilised and did not appear even in the initial leachates in Pool 1. The mannitol content of the kelp source as a function of time is shown in Fig. 2 from which it can be seen that mannitol declined from an initial value of

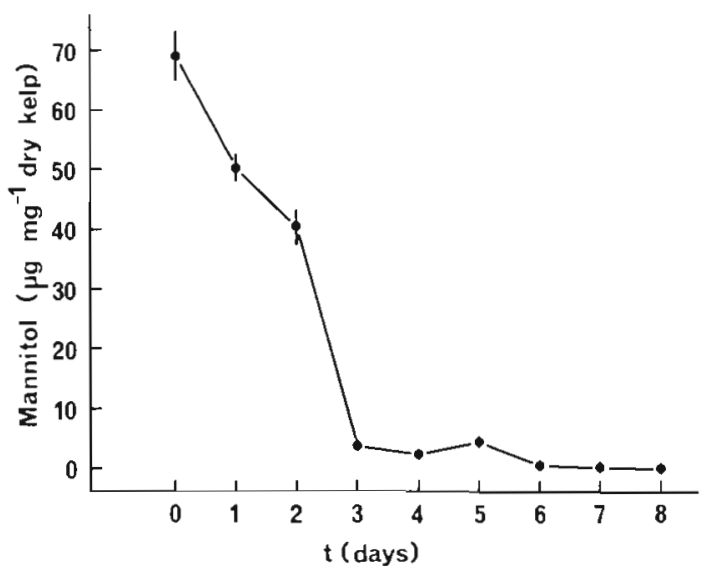

Fig. 2. Mannitol concentrations ( $\mu \mathrm{g} \mathrm{mg}^{-1}$ dry kelp) in stranded Ecklonia maxima as a function of time (d). Standard deviations shown by vertical bars 
$69.12 \mu \mathrm{g} \mathrm{mg}^{-1}$ dry kelp $(6.9 \%)$ to only $3.94 \mu \mathrm{g} \mathrm{mg}^{-1}$ dry kelp $(0.4 \%)$ by Day 3 . Clearly, this phase of rapid mannitol utilisation corresponds with the lysis of the cells and the increase in bacteria noted on p. 318 and confirms earlier observations that mannitol is capable of rapid utilisation by natural communities of kelp bed bacteria (Lucas et al., 1981; Newell and Lucas, 1981).

In contrast, no mannitol was recorded in any part of the microcosm below the kelp. Alginates and reducing sugars showed a regular increase beneath the kelp in Pool 1 (Table 6) reaching a combined concentration of $2305.2 \mathrm{mg} \mathrm{l}^{-1}$ by Day 8 . The corresponding combined concentration of alginates and reducing sugars in the interstitial water was $103.3 \mathrm{mg} \mathrm{l}^{-1}$ whilst that in drainage Pool 2 was 125.5. It is evident, therefore, that very similar trends to those for carbon occur in the transition

Table 6. Component carbohydrate values $\left(\mathrm{mg}^{-1}\right)$ in leachates from Ecklonia maxima (Pool 1), in interstitial water of a $1 \mathrm{~m}$ sand strip and a subsequent drainage pool (Pool 2). 'Sugars refers to monosaccharides, oligosaccharides, polysaccharides, i.e. reducing sugars; the values are expressed as glucose equivalents (p. 317). Note that alginates also give a weak colour response; thus 'sugars' includes a small component from these compounds (p. 317). Mannitol was not detected in the pools or the interstitial water (p. 322)

\begin{tabular}{|crrrrrr|}
\hline Day & \multicolumn{3}{c}{ Alginates } & \multicolumn{3}{c|}{ Sugars' } \\
& Pool 1 & Inter. & Pool 2 & Pool 1 & Inter. & Pool 2 \\
\hline 0 & 26.10 & 44.00 & 6.60 & 27.11 & 64.59 & 11.48 \\
1 & 34.52 & 101.70 & 24.03 & 31.74 & $($ ) & 29.31 \\
2 & 123.08 & 66.05 & 24.41 & 115.68 & 47.62 & 38.53 \\
3 & 126.18 & 61.85 & 31.54 & 228.95 & 55.64 & 49.46 \\
4 & 129.60 & 44.00 & 28.80 & 238.59 & 38.90 & 31.35 \\
5 & 158.72 & 62.90 & 27.47 & 237.41 & 55.87 & 51.12 \\
6 & 129.60 & 49.25 & 19.92 & 296.55 & 45.41 & 38.65 \\
7 & 149.16 & 47.15 & 26.51 & 318.63 & 48.20 & 49.39 \\
8 & 599.53 & 47.15 & 42.56 & 1705.67 & 56.10 & 82.91 \\
Total & 1476.49 & 469.05 & 231.84 & 3200.33 & 420.43 & 382.20 \\
\hline
\end{tabular}

from Pool 1 through the sand column to drainage Pool 2. The bacteria are clearly capable of removal of all of the mannitol prior to leachates appearing in Pool 1, and of much of the residual carbon compounds during passage through a relatively short sand strip of $1 \mathrm{~m}$. Because the carbohydrates comprise approximately $40 \%$ carbon only, it is obvious that the contribution of soluble carbohydrates to the high concentrations of carbon recorded in the microcosm (Table 5) is relatively small. The bacteria are evidently utilising both complex structural carbon compounds in the leachates as well as simpler soluble carbohydrates, leaving mainly inorganic components including relatively high concentrations of approximately $25 \mathrm{mg}$ ammonia nitrogen $\mathrm{l}^{-1}$ to be returned to the kelp bed by drainage. A similar regeneration of ammonia from shallow marine sediments has recently been reported by Raine and Patching (1980).

\section{Conversion of Kelp Carbon to Bacterial Biomass}

The amount of carbon used in the microcosm as a whole can now be calculated, since of the $26 \mathrm{~kg}$ wet kelp originally supplied, only some $8 \%$ remained at the end of the $8 \mathrm{~d}$ experiment. This loss represents a known removal by grazing (Table 4) and a known residual which leaches into the water of the microcosm (Table 5). The difference between the sum of these components and the observed loss over $8 \mathrm{~d}$ represents the amount utilised by the microheterotrophic community, both on the surface of the kelp fronds (Table 2) and in the water of the microcosm.

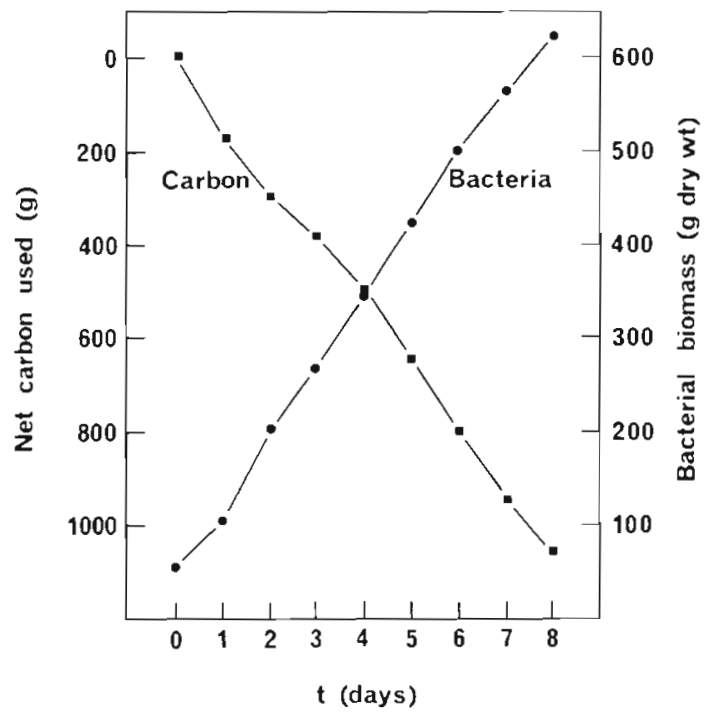

Fig. 3. Increase of bacteria ( $g$ dry weight) and simultaneous loss of carbon $(\mathrm{g})$ from microcosm over an 8 -d period

The cumulative carbon loss from the kelp and the corresponding increase in bacterial biomass in the microcosm over the $8 \mathrm{~d}$ experimental period is shown in Fig. 3. The increase in bacteria in the whole microcosm amounted to a total of $622.2 \mathrm{~g}$ dry weight, of which $619.8 \mathrm{~g}$ were associated with the surface of the kelp itself, $1.4 \mathrm{~g}$ with the leachates in Pool 1, $0.6 \mathrm{~g}$ with the interstitial water of the sand strip and $0.4 \mathrm{~g}$ with the larger volume of Pool 2. This increase was associated with a carbon loss from the kelp of $1059.4 \mathrm{~g}$. The ratio of increase in bacterial biomass per unit of kelp carbon used was thus $1059.4: 622.2 \times 100=58.7 \%$.

This gives a carbon: carbon conversion efficiency of some $29.4 \%$ since the dry weight of bacteria comprises approximately $50 \%$ carbon (Luria, 1960). The equation of the regression for increase in bacterial biomass 
per unit of kelp carbon used is $y=47.53+0.56 \times\left(r^{2}=\right.$ $0.99 ; n=9$ ) which confirms a value of $56 \%$ for bacterial production supported from kelp carbon in the microcosm. This value is within the range reported by Newell and Lucas (1981), Lucas et al. (1981) and Stuart et al. (1981) for the maximal conversion ratio obtained during the log phase of bacterial growth. They recorded values of 66 to $68 \%$ bacterial biomass per unit kelp carbon utilised from dissolved organic carbon both freely dispersed in the water column and associated with particulate debris. However, much lower values are obtained for particulate matter from which the dissolved component has been leached (Stuart et al., 1981), and over the whole growth phase from initial colonisation of dissolved organic matter to the peak in bacterial biomass.

It is possible that the decomposing kelp debris in our microcosm presented highly suitable conditions for bacterial decomposition with high temperatures of as much as $22^{\circ} \mathrm{C}$ in the kelp. The kelp debris was also already colonised by bacteria which would be selected strains capable of utilising kelp exudates, and under

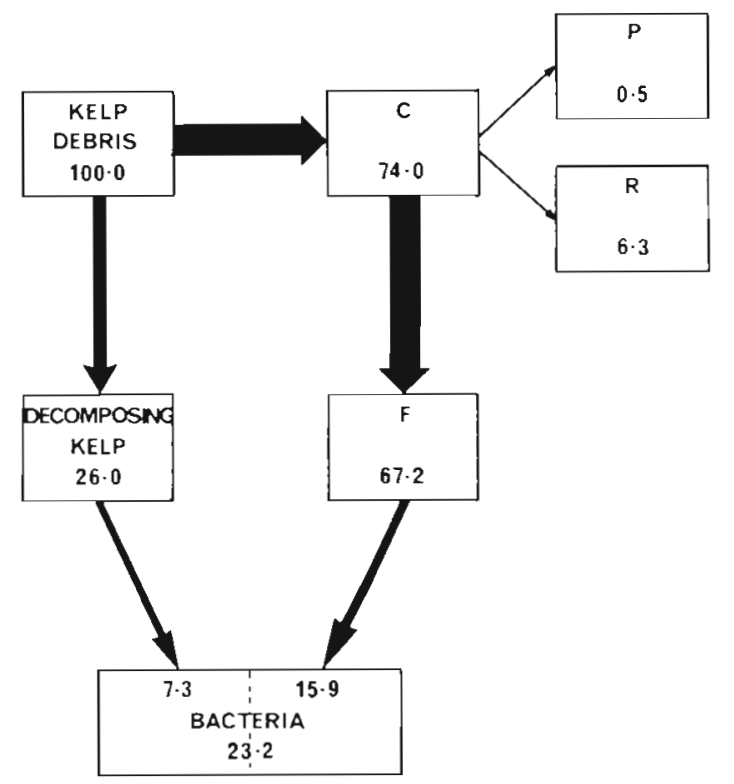

Fig. 4. Schematic flow diagram showing fate of carbon from kelp in a sandy beach microcosm. Values expressed as $g$ carbon derived from an initial $100 \mathrm{~g}$ of carbon in kelp. Consumption by invertebrates was relatively low in the microcosm, and most carbon flow was via decomposer microorganisms. For symbols consult Table 4

\footnotetext{
- We use the term 'production' here to indicate increase in biomass of bacteria per unit time, whilst conversion efficiency' is regarded as bacterial carbon 'production' per unit carbon used in the microcosm. We recognise that the value for production may be conservative if bacterial turnover rates within the microcosm are high
}

these conditions their conversion efficiency is likely to approach those recorded by Payne (1970) for selected bacterial strains rather than the lower values recorded by us for heterogeneous populations of bacteria from seawater. Thus kelp carbon: bacterial carbon conversion efficiencies apparently approached the optimal values of approximately $30 \%$ which have been obtained for dissolved organic matter in the laboratory incubation experiments of Lucas et al. (1981) and Stuart et al. (1981); (see also Linley and Newell, 1981; Newell and Lucas, 1981), and in cultured strains on a variety of substrates (Payne, 1970). A value of $28 \%$ has thus been used in our subsequent calculations of carbon flow through the sandy beach microcosm based on kelp debris. It should be emphasised, however, that lower ratios of carbon in standing stocks of bacteria per unit kelp carbon utilised may be obtained during the winter months when temperatures are lower and the bacterial composition of the kelp is different. Linley et al. (1981) have shown that small bacterial cocci dominate the laboratory incubation media in samples taken in winter and Lucas et al. (1981) reported that the biomass attained per unit dissolved carbon utilised at that time is less than half that attained in summer samples.

\section{CONCLUSIONS}

The results presented suggest that bacteria are primarily responsible for the decomposition and subsequent utilisation of kelp debris on the strandline, rather than fungi, which are generally reported to be responsible for the initial phases of decomposition of allochthonous material (Kaushik and Hynes, 1971; Gessner et al., 1972; Park, 1972; Suberkropp and Klug, 1974,1976 ). There is also a definite microbial succession: primary colonisation is effected by cocci, which become established along the superficial junctions of the epidermal cell walls (Fig. 1) where they appear to be responsible for the initial lesion processes. Cocci are succeeded by large rods which are associated with lysed cells and with the production of exudates. A similar succession has been shown to occur in incubation studies of kelp debris in seawater (Linley and Newell, 1981; Newell and Lucas, 1981; Stuart et al., 1981a; Linley et al., 1981) and the role of cocci in the initial degradation of mangrove leaves has been reported by Cundell et al. (1979). Again, HowardWilliams et al. (1978) and Robb et al. (1979) have shown that similar processes pertain to the degradation of the brackish water sago pond weed Potamogeton pectinatus, and have obtained essentially similar results to those reported here. They also describe fimbriate structures and holdfasts which they suggest may be of importance in preventing dislodgement of the 
bacteria from the leaf surface, and in the localisation of exoenzymes in a turbulent medium (see also Floodgate, 1972; Paerl, 1973, 1974). Similar fimbrae, holdfasts and fibrous web-like structures were also apparent in scanning electron micrographs of the bacterial rods which colonise kelp debris in the later phases of decomposition, although we have not examined their structure in detail.

Lysis of the cells, probably by bacterial decomposition, results in the release of high concentrations of dissolved organic matter as leachates immediately below the decomposing kelp (Table 5). Values as high as $5640 \mathrm{mg}_{\text {carbon }} \mathrm{l}^{-1}$ were recorded. It is likely that at these high concentrations such compounds may be capable of direct absorption by the meiofauna which occurs under natural conditions in more mature sand columns on open sandy beaches. A strictly localised distribution of such organisms in the leachate zone beneath the decomposing kelp debris would, however, be anticipated since over $90 \%$ of the carbon is removed by bacterial activity within only $1 \mathrm{~m}$ of sand in the microcosm (p. 321). It is therefore of considerable interest that the large populations of nematodes recorded by Koop and Griffiths (1982) are to be found in this zone. There is some experimental evidence that these organisms can absorb glucose from seawater (Stephens 1967, 1968; Chia and Warwick, 1969; Jørgensen, 1976; Meyer-Reil and Faubel, 1980), and it is of some significance that alginates and complex structural polysaccharides may be broken down to glucose by bacteria.

The results of our microcosm study, above all, allow calculation of carbon flow from kelp debris, both through the invertebrate consumers and the microbial decomposers in a sandy beach community. Fig. 4 shows that of $100.0 \mathrm{~g}$ carbon in kelp, $8.9 \%$ was consumed by invertebrates, leading to a production of $0.4 \mathrm{~g}$ carbon and an associated respiratory loss of $1.6 \mathrm{~g}$ carbon. Total faecal production from the mixed community of grazers amounted to $6.9 \%$ of the original kelp carbon (Table 4 ). The residual kelp carbon was converted to bacterial carbon in the microbial standing stock with an efficiency of $28 \%$ (p. 322), leading to $25.5 \mathrm{~g}$ bacterial carbon through this pathway. Stuart et al. (1982) have recently reported a carbon: carbon bacterial conversion efficiency on faecal material from the mussel Aulacomya ater of $6.3 \%$ for the initial brief phase of bacterial colonisation and $23.7 \%$ for the later stages of conversion of faecal material. Since bacterial populations built up extremely rapidly in our experiment it is reasonable to assume that microbial conversion of faecal material in the microcosm is similar to that measured by Stuart et al. (1982) during the later phases of degradation and we have used their value of $23.7 \%$ in our calculations. Interestingly this means

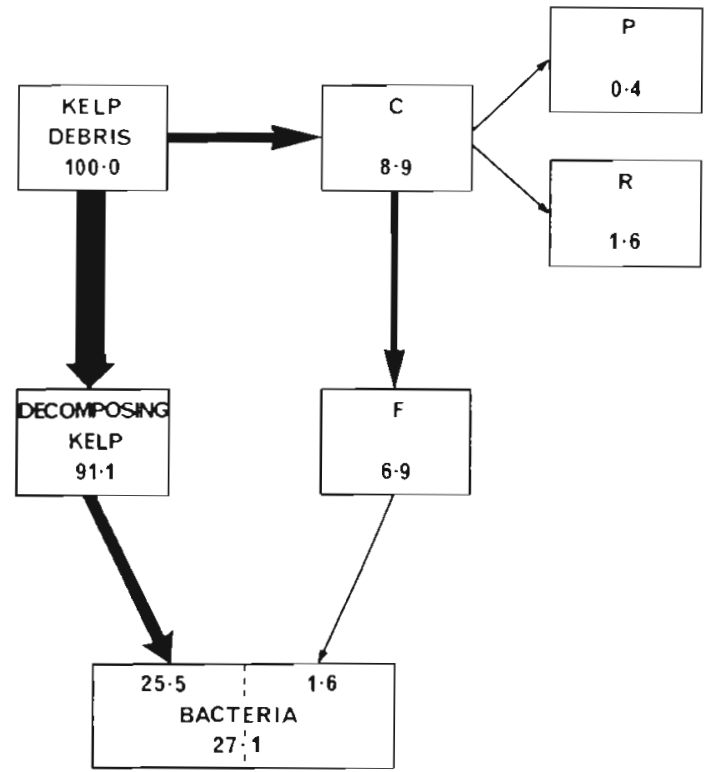

Fig. 5. Schematic flow diagram showing fate of $100 \mathrm{~g}$ carbon from kelp on the surface of an open sandy beach where grazing by invertebrates predominates over direct decomposition. Because of high faecal output of invertebrates, the combined carbon flow to bacteria is similar to that in the decomposer-dominated system. For symbols consult Table 4

that conversion of faecal matter is very similar to the $28 \%$ measured for conversion of original plant debris. We thus arrive at a predicted bacterial carbon production in a decomposer - dominated sandy beach equivalent to $27.1 \%$ of the kelp carbon on the strandline per 8 day cycle.

As pointed out on p. 321, Griffiths and StentonDozey (1981) found that in some situations up to $74 \%$ of the kelp cast up on the surface of an adjacent sandy beach at Kommetjie, on the Cape Peninsula, was consumed by the amphipod Talorchestia capensis and the dipteran larva Fucellia capensis. Using their figures for consumption by each of these organisms and the energy budget equations in Table 4 , it is possible to calculate the heterotrophic fate of kelp debris in a consumer-dominated community, such as may occur on an open sandy beach, and to compare the carbon flow with that in our decomposer-dominated microcosm. Fig. 5 shows that the consumption rate by invertebrates on the surface of the sandy beach is $74 \%$ of the kelp, compared with only $9 \%$ in the microcosm. However, as much as $67.2 \%$ of the kelp carbon consumed by invertebrates is voided as faeces. Using the conversion ratios of 28 and $23.7 \%$ for the 2 pathways, a bacterial carbon production ratio of $23.2 \%$ can be calculated for an $8 \mathrm{~d}$ period even when direct consumption by grazers is high. Both of these calculations based on carbon flow through the microcosm thus predict a large standing stock of bacteria in the sandy 
beach community, amounting (in carbon equivalents) to some 23 to $27 \%$ of the kelp carbon on the strandline.

Using the kelp deposition rate of approximately $1800.10^{6} \mathrm{~g}$ wet weight of Ecklonia maxima per metre of strandline per year (p. 315). It is possible to estimate the actual standing stocks of bacterial carbon which are likely to be in equilibrium with the kelp debris on the beach. The relevant wet weight: dry weight : carbon ratios for kelp obtained by various authors are summarised in Newell et al. (1980). From these ratios, and because the beached kelp is decomposed and replaced 4 times per month, we estimate a mean value of $1648.1 \mathrm{~g}$ of kelp carbon is deposited per metre of strandline every $8 \mathrm{~d}$. The bacterial carbon predicted from a range of conversion efficiencies of 23 to $27 \%$ would thus amount to between 379.1 and $444.9 \mathrm{~g} \mathrm{~m}^{-1}$ of beach per 8-d cycle. Interestingly, Koop and Griffiths (1982), in an independent survey of the composition of the sandy beach fauna at Kommetjie, have found a high biomass of bacteria which reaches a minimum carbon equivalent of $331.5 \mathrm{~g} \mathrm{~m}^{-1}$ of beach. This observed bacterial biomass is clearly close to our predicted value based on the decomposition of kelp debris over an 8-d cycle on the strandline, and suggests that annual carbon production by bacteria may be as high as $15 \mathrm{~kg} \mathrm{~m}^{-1}$ of beach.

Carbon flow analyses of both decomposer- and consumer-dominated systems thus suggest that some 23 to $27 \%$ of the carbon from kelp is assimilated into a large standing stock of bacterial carbon in the intertidal zone whilst the residual 73 to $77 \%$ of the carbon from kelp is rapidly mineralised by the sand beach bacteria within approximately $8 \mathrm{~d}$. Since rather similar rates of mineralisation of kelp debris by bacteria occur in the water column (Newell, 1981; Newell and Lucas, 1981), it is evident that the microbial community of the intertidal zone and immediate coastal water occupies a central role in the rapid regeneration of inorganic materials necessary to support the characteristically high primary production of the kelp bed.

Acknowledgements. This work was supported mainly by funds from SANCOR through the University of Cape Town kelp bed project, and by a Royal Society Fellowship to Professor R. C. Newell. We should like to thank the staff of the SEMunit at the University of Cape Town for assistance with electron microscopy. We are grateful for advice and comments from Professor J. G. Field, Dr. C. L. Griffiths and Mr. D. G. Muir.

\section{LITERATURE CITED}

Blumenkrantz, N., Asboe Hansen, G. (1973). New method for quantitative determination of uronic acids. Analyt. Biochem. 34: 484-489

Bowden, W. B. (1977). Comparison of two direct-count techniques for enumerating aquatic bacteria. Appl. environ. Microbiol. 33: 1229-1232
Chia, F.-S., Warwick, R. M. (1969). Assimilation of labelled glucose from seawater by marine nematodes. Nature, Lond. 224 (5220): 720-721

Cundell, A. M., Brown, M. S., Stanford, R., Mitchell, R. (1979). Microbial degradation of Rhizophora mangle leaves immersed in the sea. Estuar. coast. mar Sci. 9: 281-286

Cundell, A. M., Sleeter, T. D., Mitchell, R. (1977). Microbial populations associated with the surface of the brown alga Ascophyllum nodosum. Microb. Ecol. 4: 81-91

Dieckmann, G. S. (1978). Aspects of growth and production of Laminaria pallida (Grev.) J. Agr. off the Cape Peninsula. M. Sc. thesis, Botany Department, University of Cape Town, Rondebosch, South Africa

Dubois, M., Gilles, K. A., Hamilton, J, K., Rebers, P. A., Smith, F. (1956). Colorimetric method for determination of sugars and related substances. Analyt. Chem. 28: 350-356

Field, J. G., Jarman, N. G., Dieckmann, G. S., Griffiths, C. L. Velimirov, B., Zoutendyk, P. (1977). Sun, waves, seaweed and lobsters: the dynamics of a west coast kelp bed. S. Afr J. Sci. 73: 7-10

Field, J. G., Griffiths, C. L., Griffiths, R. J., Jamman, N. G. Zoutendyk, P., Velimirov, B., Bowes, A. (1980). Variation in structure and biomass of kelp communities along the south west Cape coast. Trans. R. Soc. S. Afr. 44: 145-203

Floodgate, G. D. (1972). The mechanism of bacterial attachment to detritus in aquatic systems. Memorie Ist. ital. Idrobiol. 29 (Suppl.): 309-323

Gessner, R. V., Goos, R. D., Sieburth, J. McN. (1972). The fungal microcosm of the internodes of Spartina alterniflora. Mar. Biol. 16: 269-273

Griffiths, C. L., Stenton-Dozey, J. (1981). The fauna and rate of degradation of stranded kelp. Estuar. coast. Shelf Sci. 12: 645-653

Hatcher, B. G., Chapman, A. R. O., Mann, K. H. (1977). An annual carbon budget for the kelp Laminaria longicruris. Mar. Biol. 44: 85-96

Hobbie, J. E., Daley, R. T., Jasper, S. (1977). Use of Nuclepore filters for counting bacteria by fluorescence microscopy. Appl. environ. Microbiol. 33: 1225-1228

Holligan, P. M., Drew, E. A. (1971). Routine analysis by gasliquid chromatography of soluble carbohydrates in extracts of plant tissues. II. Quantitative analysis of standard carbohydrates and the separation and estimation of soluble sugars and polyols from a variety of plant tissues New Phytol. 70: 271-297

Howard-Williams, C., Davies, B. R., Cross, R. H. M. (1978). The influence of periphyton on the surface structure of a Potamogeton pectinatus L. leaf. (An hypothesis.) Aquatic Botany 5: 87-91

Jarman, N. G., Carter, R. A. (1982). The primary producers of the inshore regions of the Benguela. Symposium on Upwelling Processes in the Southern Benguela Region. Trans. R. Soc. S. Afr. (in press)

Jensen, A., Stein, J. R. (eds.) (1978). Proceedings of the international seaweed symposium 9. Science Press, Princeton, USA

Jørgensen, C. B. (1976). August Putter, August Krogh, and modern ideas on the use of dissolved organic matter in aquatic environments. Biol. Rev. 51: 291-328

Johnston, C. S., Jones, R. G., Hunt, R. D. (1977). A seasonal carbon budget for a laminarian population in a $\mathrm{Scottish}$ sea loch. Helgoländer wiss. Meeresunters. 30:527-545

Kaushik, N. K., Hynes, H. B. N. (1971). The fate of dead leaves that fall into streams. Arch. Hydrobiol. 68: 465-515

Koop, K., Field, J. G. (1980). The influence of food availability on population dynamics of a supralittoral isopod, Ligia dilatata Brandt. J. exp. mar. Biol. Ecol. 48: 61-72 
Koop, K., Field, J. G. (1981). Energy transformation by the supralittoral isopod Ligia dilatata Brandt. J. exp. mar. Biol. Ecol. 53: 221-233

Koop, K., Griffiths, C. L. (1982). The relative significance of bacteria, meio- and macrofauna on an exposed sandy beach. Mar. Biol. (in press)

Laycock, R. A. (1974). The detrital food chain based on seaweeds. I Bacteria associated with the surface of Laminaria fronds. Mar. Biol. 25: 223-231

Linley, E. A. S., Newell, R. C. (1981). Microheterotrophic communities associated with the degradation of kelp debris. Kieler Meeresforsch. 5: 345-355

Linley, E. A. S., Newell, R. C., Bosma, S. A. (1981). Heterotrophic utilisation of mucilage released during fragmentation of kelp (Ecklonia maxima and Laminaria pallida). I. Development of microbial communities associated with the degradation of kelp mucilage. Mar. Ecol. Prog. Ser. 4: $31-41$

Lucas, M. I., Newell, R. C., Velimirov, B. (1981). Heterotrophic utilisation of mucilage released during fragmentation of kelp (Ecklonia maxima and Laminaria pallida). II. Differential utilisation of dissolved organic components from kelp mucilage. Mar. Ecol. Prog. Ser. 4: 43-55

Luria, S. E. (1960). The bacterial protoplasm: composition and organisation. In: Gunsalus, I. C., Stanier, R. Y. (eds.) The bacteria, Vol. 1. Academíc Press, New York, pp. 1-34

Mann, K. H., Jarman, N. G., Dieckmann, G. S. (1979). Development of a method for measuring the productivity of Ecklonia maxima (Osbeck) Papenf. Trans. R. Soc. S. Afr. $44: 27-42$

Mazure, H. G. F., Field, J. G. (1980). Density and ecological importance of bacteria on kelp fronds in an upwelling region. J. exp. mar. Biol. Ecol. 43: 173-182

Muir, D. G. (1977). The biology of Talorchestia capensis (Amphipoda: Talitridae), including a population energy budget. M. Sc. thesis, Zoology Department, University of Cape Town, Rondebosch, South Africa

Newell, R. C. (1980). The maintenance of energy balance in marine invertebrates exposed to changes in environmental temperature. In: Gilles, R. (ed.) Animals and environmental fitness. Pergamon Press, Oxford and New York

Newell, R. C. (1982). Nearshore Ecosystems: Decomposers. Symposium on Upwelling Processes in the Southem Benguela Region. Trans. R. Soc. S. Afr. (in press)

Newell, R. C., Branch, G. M. (1980). The influence of temperature on the maintenance of metabolic energy balance in marine invertebrates. Adv. mar. Biol. 17: 329-396

Newell, R. C., Lucas, M. I. (1981). The quantitative significance of dissolved and particulate organic matter released during fragmentation of kelp in coastal waters. Kieler Meeresforsch. 5: 356-369

Newell, R. C., Lucas, M. I., Velimirov, B., Seiderer, L. J. (1980). Quantitative significance of dissolved organic losses following fragmentation of kelp (Ecklonia maxima and Laminaria pallida). Mar. Ecol. Prog. Ser. 2: 45-59

Paerl, H. W. (1973). Detritus in Lake Tahoe: structural modification by attached microflora. Science, N.Y. 180: 496-498

Paerl, H. W. (1974). Bacterial uptake of dissolved organic matter in relation to detrital aggregation in marine and freshwater systems. Limnol. Oceanogr. 19: 966-972
Paerl, H. W. (1975). Microbial attachment to particles in marine and freshwater ecosystems. Mar. Ecol. 2: 73-83

Park, D. (1972). Methods of detecting fungi in organic detritus in water. Trans. Br. Mycol. Soc. 58: 281-290

Payne, W. J. (1970). Energy yields and growth of heterotrophs. A. Rev. Microbiol. 24: 17-52

Raine, R. C. T., Patching, J. W. (1980). Aspects of carbon and nitrogen cycling in a shallow marine environment. $J$. exp. mar. Biol. Ecol. 47: 127-139

Robb, F. T., Davies, B. R., Cross, R., Kenyon, C., HowardWilliams, C. (1979). Cellulolytic bacteria as primary colonizers of Potamogeton pectinatus L. (Sago pond weed) from a brackish south-temperate coastal lake. Microb. Ecol. 5: 167-177

Rodina, A. G. (1972). Methods in aquatic microbiology, University Park Press, Baltimore, USA

Sieburth, J. McN., Thomas, C. D. (1973). Fouling on eelgrass (Zostera marina L.). J. Phycol. 9: 46-50

Sorokin, Y. I., Kadota, M. (eds.) (1972). Techniques for the assessment of microbial production and decomposition in fresh waters. I. B. P. Handbook No. 23. Blackwell Sci. Publ., Oxford

Stenton-Dozey, J., Griffiths, C. L. (1980). Growth, consumption and respiration by larvae of the kelp-fly Fucellia capensis (Diptera: Anthomyiidae). S. Afr. J. Zool. 15: 280-283

Stephen, A. M. (1979). Plant carbohydrates. In: Pirson, A., Zimmermann, M. H. (eds.) Encyclopedia of plant physiology 8. Springer-Verlag, Heidelberg, pp. 555-584

Stephens, G. C. (1967). Dissolved organic matter as a nutritional source for marine and estuarine invertebrates. In: Lauff, G. H. (ed.) Estuaries. Publ. Am. Ass. Advmt Sci. 83, Washington D.C., pp. 367-373

Stephens, G. C. (1968). Dissolved organic matter as a potential source of nutrition for marine organisms. Am. Zool. 8: 95-106

Stuart, V., Lucas, M. I., Newell, R. C. (1981). Heterotrophic utilisation of particulate matter from the kelp Laminaria pallida. Mar. Ecol. Prog. Ser. 4: 337-348

Stuart, V., Newell, R. C., Lucas, M. I (1982). Conversion of kelp debris and faecal material from the mussel Aulacomya ater by marine microorganisms. Mar. Ecol. Ptog. Ser. 7: 47-57

Suberkropp, K., Klug, M. J. (1974). Decomposition of deciduous leaf litter in a woodland stream. 1. A scanning electron microscope study. Microb. Ecol. 1: 96-103

Suberkropp, K., Klug, M. J. (1976). Fungi and bacteria associated with leaves during processing in a woodland stream. Ecology 57: 707-719

Todd, R. L., Kerr, T. J. (1972). Scanning electron microscopy of microbial cells on membrane filters. Appl. Microb. 23: $1160-1162$

Troitsky, A. S., Sorokin, Y. I. (1967). On the methods of the calculation of the bacterial biomass in water bodies. Trans. Inst. Biol. Inland Waters Acad. Sci. USSR 19: 85-90

von Holdt, M. M., Ligthelm, S. P., Nunn, J. R. (1955). South African seaweeds: seasonal variations in the chemical composition of some Phaeophyceae. J. Sci. Food Agric. 6: 193-197 